\title{
MEGALOBLASTIC ANAEMIA ASSOCIATED WITH ADULT SCURVY
}

\author{
G. WILL, M.B., B.Sc., F.R.F.P.S.G. \\ Senior Medical Registrar, Glasgote Royal Infirmary
}

W. R. Мurdoch, M.B., F.R.F.P.S.G., M.R.C.P.E., M.R.C.P.

Senior Medical Registrar, Dumfries and Galloziay Royal Infirmary

Nowadays scurvy is fortunately rare. Cases are still found among the inmates of common lodging houses and those living alone, where age, decrepitude, or apathy may have led to an inadequate dietary intake. Rigid dieting as in peptic ulcer $^{1}$ may be an unusual cause.

While the blood picture may show little change in the milder cases, anaemia of variable degree occurs in most adults with scurvy. It is usually normocytic, but may be hypochromic, or occasionally macrocytic. ${ }^{18,3}$ Although the peripheral blood picture has been well described, ${ }^{2,3}, 8,11,14,18$ few authors have carried out serial examinations of the bone marrow.

It has been our custom to carry out marrow punctures in these cases, and we report here three scorbutic patients who presented with macrocytic anaemias, had megaloblastic marrows, and showed recovery on ascorbic acid.

\section{Case Reports}

Case I. D. McG. A 78-year-old male who had been in failing health for two years. During the three months prior to admission on June 16,1959 , his appetite had been poor, and he had lost weight. His diet had been inadequate and had contained no vegetables, fruit, or potatoes. On clinical examination he presented the typical picture of scurvy, with follicular hyperkeratosis, petechiae, and massive ecchymoses on the lower limbs and hands. Capillary fragility (Hess's test) was markedly increased. There was a severe macrocytic anaemia with a normal leucocyte count $(\mathrm{Hb} .8 .3 \mathrm{~g}$. per $100 \mathrm{ml}$, R.B.C. 2.4 million, W.B.C. 8,000 cells per $\mathrm{cmm}$., P.C.V. $24 \%$, M.C.V. $100 \mathrm{c} \mu$, M.C.H.C. $34 \%$ ). The serum bilirubin was $0.6 \mathrm{mg}$. per $100 \mathrm{ml}$. with a negative direct Van den Bergh reaction. The serum vitamin $B_{12}$ was $155 \mu \mu \mathrm{g}$. per $\mathrm{ml}$. The sternal marrow was megaloblastic (Fig. I). The vitamin C saturation

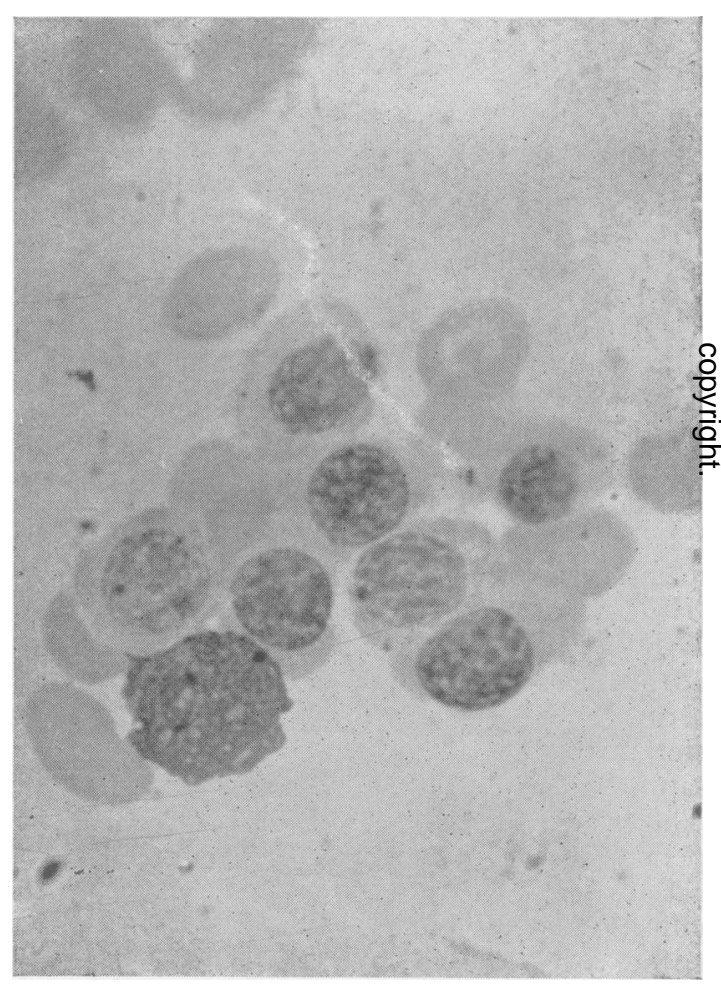

FIG. 1.-Case I. Before treatment, showing megaloblastic erythropoiesis.

test ${ }^{7}$ required 20 days for saturation. He was given an ordinary ward diet and vitamin $\mathrm{C}$ but no other haematinics. The clinical evidence of scurvy rapidly disappeared, and at the end of his period of saturation the haemoglobin had risen to $10.4 \mathrm{~g}$. per $100 \mathrm{ml}$. A further sternal marrow was normoblastic (Fig. 2).

Case 2. R.M. A 53-year-old male who attended the orthopaedic department on April 12, 1957, 


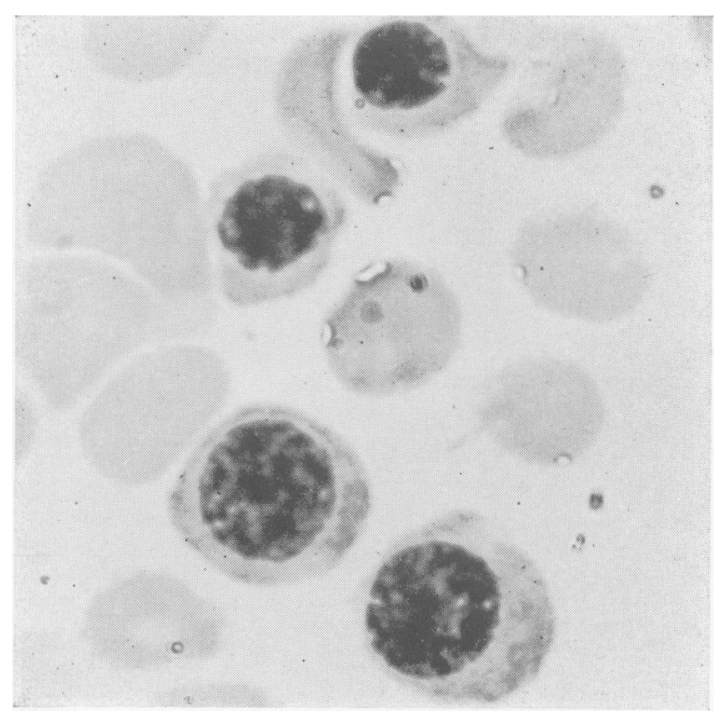

Fig. 2.-Case 2. After treatment, showing normoblastic erythropoiesis.

with a painful swelling of his left knee following a minor injury at his work. He was found to have a haemarthrosis of the left knee joint and a large adjacent ecchymosis. There were many petechiae on both lower limbs and extensive ecchymosis on the posterior aspect of the left thigh. Since the death of his wife a year before he had been living alone on an inadequate diet. The capillary fragility test was strongly positive. There was a macrocytic anaemia with a normal leucocyte count (Hb. 9.4 g. per $100 \mathrm{ml}$, R.B.C. 2.67 million, W.B.C. 7,000 cells per $\mathrm{cmm}$., P.C.V. $27 \%$, M.C.V. Ior $\mathrm{c} \mu$, M.C.H.C. $35 \%$, reticulocytes $1.5 \%$ ). The serum vitamin $\mathrm{B}_{12}$ was $300 \mu \mu \mathrm{g}$. per $\mathrm{ml}$. The sternal marrow was megaloblastic. The vitamin $\mathrm{C}$ saturation test required eight days for saturation. Thereafter he received $150 \mathrm{mg}$. of ascorbic acid per day. No other treatment was given. The clinical signs of scurvy improved rapidly. The knec effusion resolved, although there was some residual stiffness. Four weeks after admission the haemoglobin had risen to $14.1 \mathrm{~g}$. per $100 \mathrm{ml}$., and the sternal marrow was normoblastic.

Case 3. A. McC. A retired railwayman, aged 67 years. Since the death of his wife 18 months previously he had been living alone on a poor diet. He was admitted on May 20, 1959, with a painful swelling of the right leg of one month's duration. On examination the limb was swollen from the groin downwards. There were many petechiae, and extensive ccchymoses on both lower limbs. A severe macrocytic anaemia was present with a normal leucocyte count (Hb. 7 g. per $100 \mathrm{ml}$, R.B.C. 1.88 million, W.B.C. 5,000 cells per $\mathrm{cmm}$.,
P.C.V. $22 \%$, M.C.V. $118 \mathrm{c} \mu$, M.C.H.C. $32 \%$ ). The serum vitamin $B_{12}$ was $175 \mu \mu \mathrm{g}$. per ml. The sternal marrow was megaloblastic. The vitamin $\mathrm{C}$ saturation test required 20 days for saturation. On this regime the haemoglobin rose to $12.6 \mathrm{~g}$. per $100 \mathrm{ml}$., and a further sternal marrow was normoblastic.

\section{Discussion}

There is considerable divergence of opinion as to the origin and type of anaemia found in scurvy. It has not been found possible to induce anaemia in man as a result of experimental vitamin $\mathrm{C}$ deficiency. ${ }^{5,12}$ There is cvidence, however, as in our cases, that a return of the blood picture to normal can be effected by treatment with ascorbic acid. ${ }^{2,3}$

It is tempting to accept the haemorrhagic phenomena as the basis of the anaemia, but no correlation has becn shown between the extent of blood loss into tissues, and the severity of anaemia. ${ }^{3}, 11,18$

A haemolytic process is suggested by the demonstration of a reduced survival time of normal red cells transfused to scorbutic patients, using the Ashby technique. ${ }^{13}$ Similarly Vilter et al. $^{18}$ found reticulocytosis, jaundice, and elevated urine and stool urobilinogen in almost all patients. However, both Proehl and May ${ }^{16}$ and Bronte Stewart ${ }^{2}$ found no evidence of a haemolytic mechanism other than the destruction of red.cells extravasated into the tissues.

The serum $B_{12}$ levels in the above cases do not suggest that the megaloblastosis was due to exhaustion of the body vitamin $\mathrm{B}_{12}$ content.

It would seem possible that a diet defective in vitamin $\mathrm{C}$ might also be defective in folic acid, yet this is difficult to assess, as the minimum daily requirement of folic acid in the human subject is unknown. ${ }^{6}$ Ungley $^{17}$ states that nutritional megaloblastic anaemias are uncommon in temperate climates. As our cases were males who showed no evidence of malabsorption, and had not been treated with folic acid antagonists or anticonvulsants, it seems unlikely that their anaemia was due to folic acid deficiency. Therefore, it is reasonable to attribute the reversion of the marrow and the haematological response to ascorbic acid.

Folinic acid (Citrovorum factor) is believed to be the active form of folic acid. The importance of ascorbic acid in the conversion of folic acid to folinic acid has been demonstrated by May and his colleagues, ${ }^{9,10}$ who noted that megaloblastic anaemia could be produced in immature monkeys on a diet deficient in vitamin $\mathrm{C}$ if the diet were also low in folic acid. The anaemia could be cured by the administration of ascorbic acid, folic acid in large doses, or small doses of folinic acid. Nicol 
and Welch ${ }^{15}$ found that ascorbic acid augmented the transformation of folic acid to folinic acid in liver cells. It is possible that in our patients the lack of ascorbic acid led to a secondary deficiency in folinic acid.

While the anaemia of scurvy is commonly normocytic, several authors have described cases with a macrocytic blood picture, and in a few of these a megaloblastic marrow has been found ${ }^{2}, 8,11,18$; indeed pernicious anaemia was the original diagnosis made in Jenning and Glazebrook's first case. Brown, ${ }^{4}$ however, states that anaemia in adult scurvy is almost invariably normoblastic even when it is macrocytic. In his own case scurvy was associated with a multilobular cirrhosis. He was unable to find in the literature a well-authenticated case of an adult megaloblastic anaemia which responded to synthetic ascorbic acid alone. This may have been due in part to the relatively small number of marrow biopsies carried out in the main series, and to the different criteria of megaloblastosis adopted by various authors. It must be agreed, however, that his report of a case of megaloblastic anaemia associated with adult scurvy is the first article in the literature to contain an illustration of megaloblastic erythropoiesis. Our findings of megaloblastic erythropoiesis in three scorbutic adults would suggest that this picture is more common than is generally believed, and illustrates the value of routine biopsy in these cases.

\section{Summary}

Three cases of megaloblastic anaemia occurring in scurvy are described in which there was a haematological response and reversion of the marrow to normoblastic erythropoeisis following 을 the administration of synthetic ascorbic acid. The significance of these findings is discussed. Routine $\frac{\varrho}{c}$ marrow biopsy is recommended in these cases.

\section{Acknowledgments}

We are grateful to Dr. J. W. Macfarlane and Dr. J. Laurie for permitting us to report these $\frac{\bar{\sigma}}{7}$ cases and for their helpful criticism.

We are indebted to Mr. A. A. Jenkins for the microphotographs.

\section{REFERENCES}

I. ADAMS, J. F. (1954), Glasg. med. F., 35, 64.

2. BRONTE-STEWART, B. (1953), Quart F. Med., 22, 309.

3. BROWN, A. (1951), Glasg. med. f., 32, 95.

4. BROWN, A. (1955), Brit. F. Haemat., 1, 345. 4. BROWN, A. (1955), Brit. F. Haemat., I, 345.
5ew Engl. Y. Med., 223, 353. C., and DILL, D. B. (1940), O

6. GIRDWOOD, R. H. (1959), Brit. med. Bull., 15, 14.

7. HARRIS, L. J. (1943), Lancet, i, 5 I 5.

8. JENNINGS, G. H., and GLAZEBROOK, A. J. (1938), Brit. med. '尹., ii, 784 .

9. MAY, C. D., SUNDBERG, R. D., and SCHAARF, F. (1950), 음 7. Lab. clin. Med., 36, 963

Io. MAY, C. D., SUNDBERG, R. D., SCHAARF, F., L.OWE, C. V., and SALMON, R. J. (1951), Amer. $\mathscr{7}$. Dis. Child., I 82, 282.

11. McMILLAN, R. B., and INGLIS, J. C. (1944), Brit. med. F., ii, 233.

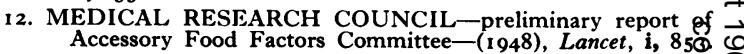

13. MERSKY, C. (1953), Brit. med. f., ii, 1353.

I4. METTIER, S. R., MINOR, G. R., and TOWNSEND, W. (1930), F. Amer. med. Ass., 95, 1089.

15. NICOL, C. A., and WELCH, A. D. (1950), Proc. Soc. exp Biol. (N.Y.), 74, 52.

16. PROEHL, E. C., and MAY, C. D. (1952), Blood, 7, 671 .

17. UNGLEY, C. C. (1955), in 'Modern Trends in Blood Diseases', ฏ p. 304 , ed. J. F. Wilkinson. London: Butterworth.

18. VILTER, R. W., WOOLFORD, R. M., and SPIES, T. D (1946), f. Lab. clin. Med., 31, 609

\section{RUTHIN CASTLE, NORTH WALES}

A Clinic for the diagnosis and treatment of Internal Diseases (except Mental or Infectious Diseases). The Clinic is provided with a staff of doctors, nurses, technicians, modern Radiological and Physiotherapy departments.

The surroundings are beautiful. The climate is mild. There is central heating throughout. The annual rainfall is 30.5 inches, that is less than the average for England.

The Fees are inclusive and vary according to the room occupied.

For particulars apply to THE SECRETARY, Ruthin Castle, North Wales. 